\title{
RESISTANCE OF Capsicum annuum GENOTYPES TO Bemisia tabaci AND INFLUENCE OF PLANT LEAF TRAITS
}

\section{RESISTENCIA DE GENOTIPOS DE Capsicum annuum A Bemisia tabaci E INFLUENCIA DE LAS CARACTERISTICAS FOLIARES}

\author{
Luis A. Hernández-Alvarado', Esaú Ruiz-Sánchez*, Luis Latournerie-Moreno', \\ René Garruña-Hernández ${ }^{2}$, Daniel González-Mendoza ${ }^{3}$ y Wilberth Chan-Cupul ${ }^{4}$
}

\begin{abstract}
${ }^{1}$ Instituto Tecnológico de Conkal, División de Estudios de Posgrado e Investigación, Conkal, Yucatán, México. ${ }^{2}$ Cátedra CONACYT-Instituto Tecnológico de Conkal, Conkal, Yucatán, México. ${ }^{3}$ Universidad Autónoma de Baja California, Instituto de Ciencias Agrícolas, Ejido Nuevo León, Mexicali, Baja California, México. ${ }^{4}$ Universidad de Colima, Facultad de Ciencias Biológicas y Agropecuarias, Tecomán, Colima, México.
\end{abstract}

*Corresponding author (esau.ruiz@itconkal.edu.mx)

\section{SUMMARY}

Bemisia tabaci (Gennadius) (Homoptera: Aleyrodidae) is one of the most damaging pests of Capsicum annuum L. (Solanales: Solanaceae) worldwide. The large genetic diversity of landrace genotypes of $C$. annuum in several regions of America offers an excellent opportunity to study the factors involved in the resistance response to $B$. tabaci. This study was carried out to evaluate the oviposition preference and nymphal mortality of $B$. tabaci in landrace genotypes of $C$. annuum and to determine whether the physical or chemical characteristics of the leaves influence this response. Oviposition preference varied among genotypes. Low oviposition preference and high nymphal mortality were observed in genotypes Amaxito and Simojovel. Oviposition preference and nymphal mortality showed no significant correlation with leaf size, leaf hardness or trichome density. The chemical composition analyses of leaves of four genotypes with differential response on nymphal mortality showed significant differences in the foliar content of $\mathrm{N}$, phenol, and total flavonoids, but there was no clear trend in the association between the nymphal mortality and chemical composition of leaves.

Index words: Chili germplasm, insect-plant interaction, plant resistance.

\section{RESUMEN}

Bemisia tabaci (Gennadius) (Homoptera: Aleyrodidae) es una de las plagas más dañinas en Capsicum annuum L. (Solanales: Solanaceae) a nivel mundial. La enorme diversidad genética de $C$. annuum en varias regiones de América ofrece una excelente oportunidad para estudiar los factores involucrados en la respuesta de resistencia a $B$. tabaci. El presente estudio se llevó a cabo para evaluar la preferencia de oviposición y mortalidad de ninfas de $B$. tabaci en genotipos criollos de $C$. annuum y determinar si las características físicas 0 químicas de las hojas influencian esta respuesta. La preferencia de oviposición varió entre genotipos. En los genotipos Amaxito y Simojovel se observó una baja preferencia de oviposición y alta mortalidad de ninfas. La preferencia de oviposición y mortalidad de ninfas no mostró correlación significativa con el tamaño de hojas, dureza foliar o densidad de tricomas. Los análisis de composición química foliar en hojas de cuatro genotipos con respuesta diferencial a la mortalidad de ninfas mostró diferencias significativas en el contenido foliar de $\mathrm{N}$, contenido de fenoles y flavonoides totales, pero no se observó una tendencia clara en la asociación entre mortalidad de ninfas y composición química del follaje.

Palabras clave: Germoplasma de chile, interacción insecto-planta, resistencia vegetal.

\section{INTRODUCTION}

Whitefly Bemisia tabaci (Gennadius) is one of the main pests of Capsicum annuum in both greenhouse and field (Gangwar and Gangwar, 2018; Padhi et al., 2017). Direct damages caused by feeding include stomatal closure, formation of chlorotic spots on leaves, formation of anthocyanin pigment and inhibition of plant growth (Hilje and Stansly, 2018). The most important damage by $B$. tabaci is the transmission of geminiviruses, begomoviruses and criminiviruses in a wide range of horticultural crops (De Marchi et al., 2017; Hernández-Espinal, 2018; Polston et al., 2014).

Resistance to B. tabaci in landrace, semi-wild and commercial genotypes has been evaluated in various vegetable crop species, such as soybean (Glycine max) (Cruz and Baldin, 2017), tomato (Solanum lycopersicum) (Oriani et al., 2011; Rakha et al., 2017), eggplant (Solanum melongena) (Hasanuzzaman et al., 2016), melon (Cucumis melo) (McCreight et al., 2017), cassava (Manihot esculenta) (Mwila et al., 2017) and pepper (Capsicum annuum) (BallinaGomez et al., 2013; Firdaus et al., 2011; Jeevanandham et al., 2018). In genotypes of $C$. annuum different degrees of resistance to $B$. tabaci have been observed (Ballina-Gomez et al., 2013; Firdaus et al., 2011; Latournerie-Moreno et al., 2015). The wide genetic variation of $C$. annuum offers an opportunity to explore host plant resistance and to study the plant traits that influence such resistance. In this sense, the genetic and morphological variability of wild populations and landrace genotypes of $C$. annuum from Southern Mexico provides an important scenario to study the role of host plant on the interaction B. tabaci-C. annuum (Aguilar-Meléndez et al., 2009; Castañón-Nájera et al., 2008).

Resistance to B. tabaci in tomato genotypes has been clearly associated with the presence of glandular 
trichomes and acyl sugar content (Baldin et al., 2005; Leckie et al., 2016; Smeda et al., 2016). In pepper, host plant resistance to $B$. tabaci has been scarcely studied. A study by Firdaus et al. (2011) found strong negative association of oviposition rate with cuticle thickness and density of glandular trichomes. No additional studies have undertaken the leaf traits on the resistance of pepper to $B$. tabaci; thus, the objective of this study was to evaluate the resistance of $C$. annuum landrace genotypes to $B$. tabaci and to determine whether this response is correlated with specific physical or chemical leaf traits.

\section{MATERIALS AND METHODS}

\section{Pepper genotypes}

Fifteen landrace genotypes of $C$. annuum, including the cultivated Huero, Dulce, $X^{\prime}$ catic, Verde and the semiwilds Maax, Blanco, Pozol, Picopaloma, Miraparriba, Pijadegato, Crespo, Chawa, Sucurre, Amaxito and Simojovel were collected in Southern Mexico (Chiapas, Campeche, Yucatan). Seeds were extracted manually from dried fruits collected in the field, home gardens or local rural markets. The commercial genotype Jalapeño was included as a control for susceptibility to $B$. tabaci.

\section{Planting and seedling management}

Seeds were immersed for $48 \mathrm{~h}$ in $250 \mathrm{mg} \mathrm{L}^{-1}$ gibberellic acid (Plant Health Care, Mexico) under constant oxygenation by using an aquarium air pump (Elite $\left.{ }^{\circledR}, U S A\right)$ to homogenize germination. Seeds were sown in 200 square plug polystyrene trays $(45 \times 70 \mathrm{~cm})$ in a sphagnum peat moss substrate (Cosmocel, Mexico). The substrate was maintained at $60 \%$ moisture. The seedlings were fertilized with 19N:19P.19K (Poly-feed triple 19, Haifa, Mexico) at 2 $\mathrm{g} \mathrm{L}^{-1}$ dissolved in the irrigation water. Thirty-five days after sowing, the seedlings were individually transplanted in 2 $L$ pots containing substrate composed of red soil, peat moss and fine gravel in a weight proportion of 50, 30 and $20 \%$, respectively. Plants in pots were fertilized with $4.5 \mathrm{~g}$ $\mathrm{L}^{-1}$ of the previously described fertilizer. Plants were kept into a greenhouse at the Instituto Tecnológico de Conkal, where the experiments were carried out, for 10 days after transplanting plants (45 days after sowing).

\section{Colony of Bemisia tabaci}

Adult whiteflies (B. tabaci) were originally collected from habanero pepper (Capsicum chinense Jacq.) agroecosystems in Conkal, Yucatan, Mexico. The stock colony was reared on habanero pepper into a greenhouse at the Instituto Tecnológico de Conkal, Yucatan, Mexico. To have homogeneous cohorts of $B$. tabacifor the experiments, a separated colony was maintained and reproduced on healthy plants of habanero pepper in entomological cages $(1.2 \times 1.2 \times 1.2 \mathrm{~m})$ made of aluminum and antiaphid mesh and placed under the same greenhouse as the stock colony (Ballina-Gomez et al., 2013). Adults from homogeneous cohorts (1-2 days old) were collected with a small mouth operated aspirator made of a $50 \mathrm{~mL}$ glass jar with two openings on the screwable cap, one opening was connected to $1-\mathrm{cm}$ diameter rubber tube and the other one was connected to a 5-mm diameter rigid plastic tube.

The free ending of the rigid plastic tube was placed on leaves where $B$. tabaci adults were settled, while a gently suction was applied with the mouth to the free ending of the rubber tube. Adults were kept in the glass jar for no more than 5 min before being transferred to the entomological cages for the bioassay on oviposition preference or being transferred to a fridge at $4-5^{\circ} \mathrm{C}$ where they were briefly chilled (1-2 minutes) to immobilize. Immobilized adults were observed under the stereomicroscope. Females were separated based on body size and abdomen shape. Adult females were then immediately transferred to the clip cages with the aid of a fine camel-hair brush for the experiments on nymphal mortality.

\section{Bioassay of oviposition preference}

For oviposition preference, free-choice bioassay was performed as described by Ballina-Gómez et al. (2013). Healthy plants (45 days after sowing) were kept in entomological cages as previously described for whitefly rearing. Ten cages were set up for this experiment. A single cage contained 32 randomly distributed plants (two plants of each genotype). In total, 20 plants per pepper genotype were evaluated. A plant represented a replicate. Infestation of plants set in the entomological cages was carried out with unsexed adults. Individuals were released from the glass jar placed in the center of the cage. Each cage received 640 adults (average rate of 20 individuals per plant). Oviposition was evaluated $2 \mathrm{~d}$ after adult release in two leaves of the upper third section of plants. The number of eggs per leaf was recorded using a stereoscopic microscope at 40X (Leica Co., Jalisco, Mexico). After egg counting, leaf area $\left(\mathrm{cm}^{2}\right)$ was individually measured with an area meter (LI3100, LiCOR, Lincoln, Nebraska, USA). Environmental conditions inside the cages were $18-35^{\circ} \mathrm{C}$ of temperature, $65-95 \%$ of relative humidity and natural photoperiod of 13:11 h (light:dark).

\section{Evaluation of nymphal mortality}

To evaluate nymphal mortality, the clip cage procedure was used to obtain a homogeneous cohort of nymphs as described by Ballina-Gómez et al. (2013) and Firdaus 
et al. (2011). Briefly, 20 adult females were confined in a section $\left(1 \mathrm{~cm}^{2}\right)$ of a fully expanded young leaf of a plant, after $24 \mathrm{~h}$, the adults were removed. Some eggs were also removed to left groups of 25 eggs per leaf section. The leaf section with the eggs was enclosed again with the clip cage to prevent migration of first-instar nymphs. After 15 $\mathrm{d}$ after the eggs were laid, leaves were cut and nymphal mortality was evaluated by observing the leaf sections with nymphs in a stereoscopic microscope at 40X (BME; Leica, Jalisco, Mexico). Nymphs were considered dead if they were blackish, deformed or dry (Ballina-Gomez et al., 2013). Twenty leaves (one per plant) were evaluated per genotype. A leaf represented a replicate. A second assay of nymphal mortality was conducted with only four genotypes, including two that produced high mortality and two that produced low mortality of B. tabaci nymphs. The environmental conditions for the assays of nymphal mortality were the same as described for the oviposition preference study.

\section{Evaluation of morphological leaf traits}

Evaluations were performed in fully expanded young leaves of the upper stratum of plants. For all traits, a leaf represented a replicate. Each trait was assessed in a separated group of plants. Trichome density was evaluated in two leaves per plant. Forty leaves were assessed per genotype. The classification system consisted of five levels or classes of trichome density (Matos et al., 2011), where the approximate average of trichomes in $5 \mathrm{~cm}^{2}$ of leaf section was 0 for class $1,8.7$ for class 2, 73.6 for class 3, 211.7 for class 4 and 900.2 for class 5. Leaf area was measured with a leaf area meter (LI3100C, LI-COR, Lincoln, NE, USA) in two leaves per plant. Twenty plants (40 leaves) were assessed per genotype. Leaf toughness was determined using a TA Plus Penetrometer (Texture Technologies, Hamilton, MA, USA). Leaf toughness was reported as the force required to punch a 4- $\mathrm{cm}^{2}$ leaf section; the values were given in $\mathrm{kg}$ $\mathrm{cm}^{-2} \mathrm{~s}^{-1}$. One leaf per plant was used. Twenty plants were assessed per genotype.

\section{Chemical composition of leaves}

After performing the second assay of nymphal mortality on four pepper genotypes with differential responses on nymphal mortality, four leaves of the middle and upper strata per plant were cut and pooled, which made a group of 80 leaves in total per genotype. Then, four groups of 20 leaves were formed, washed with distilled water containing $5 \%$ neutral detergent (Extran MA02 $5 \%$ ) and rinsed with distilled water. Each group of 20 leaves was placed in a paper bag and dried at $45^{\circ} \mathrm{C}$ for $72 \mathrm{~h}$. Four samples of 3 $\mathrm{g}$ of dried leaves were taken per genotype. Each sample represented a replicate. The nitrogen content of samples was determined by the Kjeldahl method. The content of $\mathrm{P}$ and $\mathrm{K}$ was determined by the wet digestion method Quantification of mineral elements was carried out by atomic absorption spectroscopy. Total phenolic content ( $\mathrm{g}$ equivalent of gallic acid per $\mathrm{g}$ of dry mass) was determined by the Folin-Ciocalteau method and total flavonoid content ( $g$ equivalent of quercetin per $g$ of dry mass) by the aluminum chloride colorimetric method as described by Hossain et al. (2011).

\section{Experimental design and data analysis}

The experiment was set under a completely randomized design. The pepper genotypes represented the treatments. All data were checked for normality and homoscedasticity. Results for oviposition, nymphal mortality, leaf area and leaf toughness in the 16 genotypes were analyzed by one-way analysis of variance and the Scott-Knott multiple comparison test. This test consists of a cluster analysis when a large amount of means is compared (Scott and Knott, 1974). Results of trichome density were analyzed by the nonparametric Kruskal-Wallis test. To determine the relationship between physical leaf traits with oviposition preference or nymphal mortality, an analysis of correlation was performed.

Data of the second assay of nymphal mortality and chemical composition of leaves were analyzed by analysis of variance and Tukey's multiple comparison tests. All data analyses were carried out in InfoStat software (InfoStat, Cordoba, Argentina). Differences were considered significant if $\mathrm{P} \leq 0.05$.

\section{RESULTS}

\section{Oviposition preference and nymphal mortality}

Results showed significant differences in oviposition preference of $B$. tabaci among $C$. annuum genotypes ( $P$ $=0.0042$ ). The density of whitefly eggs on the genotypes Jalapeño, Pijadegato, Crespo, X'catic, Chawa, Verde Sucurre, Amaxito and Simojovel (range of 0.19 to 1.7 eggs $\mathrm{cm}^{-2}$ ) was significantly lower than that of the genotypes Huero, Maax, Blanco, Pozol and Pico Paloma, with 4.3, 3.6, 3.3, 3.1 and 3.1 eggs $\mathrm{cm}^{-2}$ on their leaves, respectively (Table 1).

Nymphal mortality was significantly different among genotypes $(P=0.001)$. Nymphal mortality was higher on genotypes Pijadegato (45.4\%), Simojovel (51.6 \%) and Amaxito (59.9\%) than on the other genotypes (Table 1). 
Table 1. Response of Capsicum annuum genotypes to Bemisia tabaci and physical characteristics of leaves.

\begin{tabular}{|c|c|c|c|c|c|}
\hline \multirow[b]{2}{*}{ Genotypes } & \multicolumn{2}{|c|}{ Host resistance response } & \multicolumn{3}{|c|}{ Leaf traits } \\
\hline & 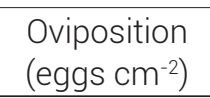 & $\begin{array}{c}\text { Nymphal } \\
\text { mortality (\%) }\end{array}$ & $\begin{array}{l}\text { Leaf area } \\
\left(\mathrm{cm}^{2}\right)\end{array}$ & $\begin{array}{l}\text { Leaf toughness } \\
\left(\mathrm{kg} \mathrm{cm}^{-2} \mathrm{~s}^{-1}\right)\end{array}$ & $\begin{array}{c}\text { Trichome density } \\
\text { (Class) }\end{array}$ \\
\hline Huero & $4.30 \pm 0.87 a$ & $01.74 \pm 00.8 b$ & $7.69 \pm 0.47 b$ & $0.82 \pm 0.01 b$ & $1 \mathrm{c}$ \\
\hline Maax & $3.60 \pm 0.70 a$ & $19.80 \pm 02.7 b$ & $3.79 \pm 0.47 d$ & $0.92 \pm 0.03 a$ & $3 b$ \\
\hline Blanco & $3.34 \pm 1.60 \mathrm{a}$ & $19.01 \pm 07.0 \mathrm{~b}$ & $4.67 \pm 0.47 d$ & $0.78 \pm 0.05 b$ & $3 b$ \\
\hline Pozol & $3.14 \pm 0.97 a$ & $14.80 \pm 11.2 b$ & $3.54 \pm 0.47 d$ & $0.80 \pm 0.06 b$ & $1 \mathrm{c}$ \\
\hline Picopaloma & $3.09 \pm 0.81 b$ & $13.28 \pm 04.9 b$ & $5.82 \pm 0.47 c$ & $0.89 \pm 0.02 \mathrm{a}$ & $4 a$ \\
\hline Miraparriba & $1.66 \pm 1.40 b$ & $15.82 \pm 04.7 b$ & $5.31 \pm 0.47 c$ & $0.79 \pm 0.01 b$ & $3 b$ \\
\hline Jalapeño & $1.54 \pm 0.52 b$ & $17.03 \pm 02.7 b$ & $5.64 \pm 0.47 c$ & $0.83 \pm 0.02 b$ & $2 c$ \\
\hline Dulce & $1.54 \pm 0.54 b$ & $28.45 \pm 05.9 b$ & $4.00 \pm 0.47 d$ & $0.84 \pm 0.03 b$ & $1 \mathrm{c}$ \\
\hline Pijadegato & $1.52 \pm 0.46 b$ & $45.40 \pm 07.9 a$ & $7.48 \pm 0.47 b$ & $0.79 \pm 0.03 b$ & $3 b$ \\
\hline Crespo & $1.09 \pm 0.74 b$ & $04.51 \pm 01.5 b$ & $3.25 \pm 0.47 d$ & $0.88 \pm 0.02 a$ & $3 b$ \\
\hline$X^{\prime}$ catic & $0.96 \pm 0.22 b$ & $13.93 \pm 04.0 \mathrm{~b}$ & $4.29 \pm 0.47 d$ & $0.89 \pm 0.01 \mathrm{a}$ & $2 c$ \\
\hline Chawa & $0.83 \pm 0.42 b$ & $07.00 \pm 03.4 b$ & $3.00 \pm 0.47 d$ & $0.96 \pm 0.029 a$ & $4 \mathrm{a}$ \\
\hline Verde & $0.74 \pm 0.48 b$ & $31.40 \pm 08.2 b$ & $3.81 \pm 0.47 d$ & $0.89 \pm 0.02 \mathrm{a}$ & $3 b$ \\
\hline Sucurre & $0.67 \pm 0.20 b$ & $17.39 \pm 07.7 b$ & $9.87 \pm 0.47 a$ & $0.81 \pm 0.04 b$ & $3 b$ \\
\hline Amaxito & $0.66 \pm 1.40 b$ & $59.90 \pm 08.9 a$ & $6.03 \pm 0.47 c$ & $0.95 \pm 0.02 a$ & $3 b$ \\
\hline Simojovel & $0.19 \pm 0.08 b$ & $51.60 \pm 11.9 a$ & $1.44 \pm 0.47 \mathrm{e}$ & $0.89 \pm 0.03 a$ & $4 a$ \\
\hline
\end{tabular}

Mean values \pm standard error with different letter within the same column are significantly different (Scott-Knott test, P $\leq 0.05$ ). Values of trichome density are in categorical data, from a five-classes scale described by Matos et al. (2011).

Table 2. Pearson correlation coefficients ( $r$ ) between physical leaf traits and host response to Bemisia tabaci.

\begin{tabular}{lll}
\hline Leaf traits & Oviposition preference $\left(\right.$ eggs $\left.\mathrm{cm}^{-2}\right)$ & Nymphal mortality $(\%)$ \\
\hline Leaf area $\left(\mathrm{cm}^{-2}\right)$ & $0.166(P=0.27)$ & $-0.065(P=0.40)$ \\
Trichome density $($ Class 1-5) & $-0.381(P=0.07)$ & $0.25(P=0.17)$ \\
Leaf toughness $\left(\mathrm{kg} \mathrm{cm}^{-2} \mathrm{~s}^{-1}\right)$ & $-0.341(P=0.09)$ & $0.18(P=0.25)$ \\
\hline
\end{tabular}

\section{Physical leaf traits}

Physical leaf traits (trichome density, leaf area and leaf toughness) varied among $C$. annuum genotypes. Leaf area showed significant differences among genotypes $(\mathrm{P}=$ 0.001 ). High density of trichomes (class 4 ) was observed in leaves of the genotypes Picopaloma, Chawa and Simojovel, whereas the lower density of trichome (class 1) was observed in leaves of Huero, Pozol and Dulce (Table 1). The highest leaf area was observed in the genotypes Sucurre $\left(9.87 \mathrm{~cm}^{2}\right)$, Huero $\left(7.69 \mathrm{~cm}^{2}\right)$ and Pijadegato $\left(7.48 \mathrm{~cm}^{2}\right)$, and the lowest leaf area was recorded in Simojovel (1.44 $\left.\mathrm{cm}^{2}\right)($ Table 1). Leaf toughness was higher $(P=0.0001)$ in the genotypes Maax $\left(0.92 \mathrm{~kg} \mathrm{~cm}^{-2} \mathrm{~s}^{-1}\right)$, Picopaloma $(0.89 \mathrm{~kg}$ $\left.\mathrm{cm}^{-2} \mathrm{~s}^{-1}\right)$, Crespo $\left(0.88 \mathrm{~kg} \mathrm{~cm}^{-2} \mathrm{~s}^{-1}\right), X^{\prime}$ catic $\left(0.89 \mathrm{~kg} \mathrm{~cm}^{-2} \mathrm{~s}^{-1}\right)$, Chawa $\left(0.96 \mathrm{~kg} \mathrm{~cm}^{-2} \mathrm{~s}^{-1}\right)$, Verde $\left(0.89 \mathrm{~kg} \mathrm{~cm}^{-2} \mathrm{~s}^{-1}\right)$, Amaxito $\left(0.95 \mathrm{~kg} \mathrm{~cm}^{-2} \mathrm{~s}^{-1}\right)$ and Simojovel $\left(0.89 \mathrm{~kg} \mathrm{~cm}^{-2} \mathrm{~s}^{-1}\right)$ relative to that of the other genotypes (Table 1).
Slight negative correlation was observed between trichome density and B. tabaci egg density; likewise, between leaf toughness and egg density; however, these correlations were not significant $(P>0.05)$ (Table 2).

\section{Chemical composition of leaves}

The second assessment of nymphal mortality on four genotypes with differential response to $B$. tabaci showed that nymphal mortality on Simojovel $(85.1 \pm 3.9 \%)$ and Amaxito $(98.3 \pm 2.3 \%)$ was significantly higher than that on $X^{\prime}$ catik $(11.8 \pm 4.1 \%)$ and Jalapeño $(25.7 \pm 6.5 \%)$. Analysis of mineral elements in leaves of these genotypes showed that the content of $\mathrm{N}$ in Simojovel was significantly higher than that in Amaxito. In contrast, no differences were observed in content of $\mathrm{P}$ and $\mathrm{K}$ among genotypes (Table 3 ). Total phenolics and flavonoids in leaves were significantly different among genotypes. The genotype $X^{\prime}$ catic had the highest content of total phenolics, whereas the content of 
Table 3. Mean content ( \pm standard error) of $\mathrm{N}, \mathrm{P}$ and $\mathrm{K}$ in leaves of Capsicum annuum genotypes.

\begin{tabular}{lccc}
\hline Genotypes & $N(\%)$ & $P(p p m)$ & $K(p p m)$ \\
\hline Amaxito & $4.27 \pm 0.08 \mathrm{~b}$ & $931.6 \pm 82.9 \mathrm{a}$ & $8837.5 \pm 673.8 \mathrm{a}$ \\
Jalapeño & $4.37 \pm 0.14 \mathrm{ab}$ & $893.7 \pm 80.5 \mathrm{a}$ & $9697.6 \pm 329.0 \mathrm{a}$ \\
Simojovel & $4.66 \pm 0.04 \mathrm{a}$ & $933.0 \pm 61.3 \mathrm{a}$ & $8318.3 \pm 191.5 \mathrm{a}$ \\
$X^{\prime}$ catic & $4.43 \pm 0.03 \mathrm{ab}$ & $1101.7 \pm 51.0 \mathrm{a}$ & $9699.4 \pm 544.2 \mathrm{a}$ \\
\hline
\end{tabular}

Mean values with different letter within the same column are significantly different (Tukey, $\mathrm{P} \leq 0.05$ ).

Table 4. Mean content ( \pm standard error) of total phenolics and flavonoids in leaves of Capsicum annuum genotypes.

\begin{tabular}{lcc}
\hline Genotypes & Phenolics $\left(\mathrm{mg} \mathrm{g}^{-1} \mathrm{dry} \mathrm{mass}^{\dagger}\right.$ & ${\text { Flavonoids }\left(\mathrm{mg} \mathrm{g}^{-1} \mathrm{dry} \mathrm{mass}^{++}\right.}^{++}$ \\
\hline Amaxito & $8.79 \pm 1.61 \mathrm{~b}$ & $17.25 \pm 2.17 \mathrm{~b}$ \\
Jalapeño & $7.82 \pm 0.64 \mathrm{bc}$ & $24.17 \pm 0.89 \mathrm{a}$ \\
Simojovel & $3.16 \pm 0.42 \mathrm{c}$ & $20.30 \pm 1.23 \mathrm{ab}$ \\
X'catic $^{\prime}$ & $15.11 \pm 1.78 \mathrm{a}$ & $22.36 \pm 1.34 \mathrm{ab}$ \\
\hline
\end{tabular}

${ }^{\dagger}$ For the calculation of total phenolics, the contents are presented as mg equivalent of gallic acid per $\mathrm{g}$ of leaf dry mass. ${ }^{\mathrm{tt}}$ For the calculation of total flavonoids, the contents are presented as mg equivalent of quercetin per $\mathrm{g}$ of leaf dry mass. Mean values with different letter within the same column are significantly different (Tukey, $\mathrm{P} \leq 0.05$ ).

flavonoids was significantly higher in leaves of Jalapeño compared to that in Amaxito (Table 4).

\section{DISCUSSION}

Genetic diversity of pepper genotypes in Southern Mexico offers an excellent opportunity to study the response of landrace genotypes to $B$. tabaci, as well as to determine the possible influences of leaf physical and chemical traits on host plant response.

In the present study oviposition preference and nymphal mortality of B. tabaci varied among pepper genotypes. Genotypes that had low oviposition preference or caused high nymphal mortality on B. tabaci have strategies to counteract the settling and colonization by this pest. In general, low oviposition preference by $B$. tabaci has been related to antixenosis, whereas nymphal mortality has been related to antibiosis (Horas et al., 2018). The present study suggests that antixenosis was present in some genotypes as Simojovel, Amaxito and Sucurre, which showed low oviposition by B. tabaci. Also it is likely that antibiosis was present in some genotypes as Simojovel, Amaxito and Pijadegato, as high nymphal mortality was observed in these genotypes; however, this is difficult to confirm and more experimental evidence is needed to show that nymphs feed on these genotypes and nymphal mortality is the result of such feeding.

In other studies differential response of $B$. tabaci to $C$. annuum genotypes has been found, but the contribution of plant leaf traits was not assessed (Ballina-Gomez et al.,
2013). In this study, in an attempt to determine possible associations between leaf traits and resistance to $B$. tabaci, the physical characteristics and the chemical composition of leaves were evaluated, with large variation only in physical leaf traits (leaf area, leaf toughness and trichome density) among genotypes. In agreement with this study, Matos et al. (2011) and Firdaus et al. (2011) documented high variation in morphological characteristics of leaves in C. annuum. Some of these characteristics, as trichome density and leaf toughness have been strongly related to host plant defense to phytophagous insects (Belete, 2018). In the present study there was only slight negative correlation between trichome density and oviposition preference, and between leaf toughness and oviposition preference, but no association was found between the morphological leaf traits and nymphal mortality.

Trichome density is considered one of the principal defense mechanisms against B. tabaci in solanaceaus crops (Leckie et al., 2016). Experiments on wild tomatoes and wild peppers showed that oviposition preference of $B$. tabaci and density of glandular trichomes had a negative strong correlation. High density of glandular trichomes resulted in high deterrence of landing and settling of $B$. tabaci and consequently in low oviposition rates (Firdaus et al., 2012; Rakha et al., 2017; Rodríguez-López et al., 2011). While glandular trichomes affect oviposition due to a wide array of volatiles and secondary metabolites that are emitted by these structures, regular trichomes affect oviposition as a physical barrier (Dalin et al., 2008; Rakha et al., 2017). 
Leaf toughness is another well characterized mechanism involved in host plant resistance to phytophagous insects. In general, leaf toughness has been implicated in the decrease of feeding in phytophagous insects (Bellota et al., 2013; Dalin et al., 2008; Westbrook et al., 2011); however, in the present study, leaf toughness showed a slight negative correlation with $B$. tabaci oviposition preference, but not with nymphal mortality, suggesting that in pepper tough leaves could prevent oviposition by B. tabaci, but once oviposition has taken place, survival of nymphs is not affected.

The content of minerals in leaves may alter the preference and survivorship of a wide variety of phytophagous insects (Athey and Connor, 1989; Casotti and Bradley, 1991). Host plant resistance to phytophagous insects depends also on their nutritional components, such as the content of nitrogen, carbon and phenolic compounds (Lowman and Box, 1983; Ohmart et al., 1987). In the association B. tabaci-C. annuum, no studies have undertaken the influence of chemical composition of leaves on host plant response. In the present study, the content of $N, P, K$, total phenolics and flavonoids was measured in leaves of four genotypes with differential response to $B$. tabaci where two genotypes caused low nymphal mortality (Jalapeño and $X^{\prime}$ 'catic) and two genotypes caused high mortality (Amaxito and Simojovel).

Slight differences in foliar content of $\mathrm{N}$ were found among pepper genotypes, but no significant trend was observed between the content of $\mathrm{N}$ in leaves and the nymphal mortality. No clear trend were observed between the content of total phenolics/flavonoids and nymphal mortality either, even though the presence of these compounds in leaves has been strongly associated to the plant defense against leaf chewer and sap sucker insects (War et al., 2012). Overall then, no influence of chemical composition of leaves of $C$. annuum was found on nymphal mortality of B. tabaci.

In short, landrace genotypes of $C$. annuum have a differential response to oviposition preference and mortality of B. tabaci nymphs. Some genotypes, as Amaxito and Simojovel caused high mortality to B. tabaci nymphs. Physical traits of $C$. annuum leaves, as leaf area, leaf toughness and thrichome density were not associated to the oviposition preference or nymphal mortality of $B$. tabaci. Likewise, chemical traits of leaves, as the content of total phenolics, flavonoids and mineral content (N, P and $\mathrm{K})$ were not associated with nymphal mortality of $B$. tabaci. Other host plant traits (chemical and physical) might be involved in mediating the interaction between $B$. tabaci and C. annuum.

\section{CONCLUSIONS}

Landrace genotypes of $C$. annuum showed differences in leaf traits (leaf area, leaf toughness and trichome density) and differential response to oviposition and nymphal mortality of $B$. tabaci. The genotypes Amaxito and Simojovel deter B. tabaci oviposition and caused high mortality on nymphs. Oviposition preference of B. tabaci had slight negative correlation with trichome density and leaf toughness, whereas nymphal mortality was not associated to any of these physical leaf traits. Genotypes with differential response to nymphal mortality showed no association between this trait and the leaf content of mineral elements ( $\mathrm{N}, \mathrm{P}$ and $\mathrm{K}$ ), total phenolics or total flavonoids.

\section{ACKNOWLEDGMENTS}

Authors thank CONACYT for the funding of this project (grant CB-83498) and for the M.Sc. scholarship granted to the first author.

\section{BIBLIOGRAPHY}

Aguilar-Meléndez A., P. L. Morrell, M. L. Roose and S. C. Kim (2009) Genetic diversity and structure in semiwild and domesticated chiles (Capsicum annuum; Solanaceae) from Mexico. American Journal of Botany 96:1190-1202, https://doi.org/10.3732/ajb.0800155

Athey L. A. and E. F. Connor (1989) The relationship between foliar nitrogen content and feeding by Odontota dorsalis Thun. on Robinia pseudoacacia L. Oecologia 79:390-394, https://doi. org/10.1007/BF00384319

Baldin E. L. L., J. D. Vendramim e A. L. Lourenção (2005) Resistência de genótipos de tomateiro à mosca-branca Bemisia tabaci (Gennadius) Biótipo B (Hemiptera: Aleyrodidae). Neotropical Entomology 34:435-441.

Ballina-Gomez H., E. Ruiz-Sánchez, W. Chan-Cupul, L. Latournerie-Moreno, L. Hernández-Alvarado, I. Islas-Flores \& J. J. Zuñiga-Aguilar (2013) Response of Bemisia tabaci Genn. (Hemiptera: Aleyrodidae) biotype B to genotypes of pepper Capsicum annuum (Solanales: Solanaceae). Neotropical Entomology 42:205-210, https://doi.org/10.1007/s13744-012-0106-0

Belete T. (2018) Defense mechanisms of plants to insect pests: from morphological to biochemical approach. Trends in Technical and Scientific Research 2:1-9.

Bellota E., R. F. Medina and J. S. Bernal (2013) Physical leaf defensesaltered by Zea life-history evolution, domestication, and breeding-mediate oviposition preference of a specialist leafhopper. Entomologia Experimentalis et Applicata 149:185195, https://doi.org/10.1111/eea.12122

Casotti G. and J. S. Bradley (1991) Leaf nitrogen and its effects on the rate of herbivory on selected eucalypts in the Jarrah forest. Forest Ecology and Management 41:167-177, https://doi.org/10.1016/0378-1127(91)90101-Z

Castañón-Nájera G., L. Latournerie-Moreno, M. Mendoza-Elos, A. VargasLópez y H. Cárdenas-Morales (2008) Colección y caracterización de chile (Capsicum spp) en Tabasco, México. Phyton 77:189202.

Cruz P. L. and E. L. L. Baldin (2017) Performance of Bemisia tabaci biotype B on soybean genotypes. Neotropical Entomology 46:210-215, https://doi.org/10.1007/s13744-016-0445-3

Dalin P., J. Ågren, C. Björkman, P. Huttunen and K. Kärkkäinen (2008) Leaf trichome formation and plant resistance to herbivory. In: 
Induced Plant Resistance to Herbivory. A. Schaller (ed.). Springer. Dordrecht, The Netherlands. pp:89-105, https://doi.org/10.1007/978-1-4020-8182-8_4

De Marchi B. R., J. M. Marubayashi, G. M. Favara, V. A. Yuki, L. F. M. Watanabe, L. F. Barbosa, M. A. Pavan and R. Krause-Sakate (2017) Comparative transmission of five viruses by Bemisia tabaci NW2 and MEAM1. Tropical Plant Pathology 42:495499, https://doi.org/10.1007/s40858-017-0186-9

Firdaus S., A. van Heusden, A. Harpenas, E. D. J. Supena, R. G. F. Visser and B. Vosman (2011) Identification of silverleaf whitefly resistance in pepper. Plant Breeding 130:708714, https://doi.org/10.1111/j.1439-0523.2011.01894.x

Firdaus S., A. W. van Heusden, N. Hidayati, E. D. J. Supena, R. G. F. Visser and B. Vosman (2012) Resistance to Bemisia tabaci in tomato wild relatives. Euphytica 187:31-45, https://doi.org/10.1007/ s10681-012-0704-2

Gangwar R. K. and C. Gangwar (2018) Lifecycle, distribution, nature of damage and economic importance of whitefly, Bemisia tabaci (Gennadius). Acta Scientific Agriculture 2:36-39.

Hasanuzzaman A. T. M., M. N. Islam, Y. Zhang, C. Y. Zhang and T. X. Liu (2016) Leaf morphological characters can be a factor for intra-varietal preference of whitefly Bemisia tabaci (Hemiptera: Aleyrodidae) among eggplant varieties. PLOS ONE 11:e0153880, https://doi. org/10.1371/journal.pone.0153880

Hilje L. and P. A. Stansly (2018) Preferencia de hospedantes por dos biotipos de Bemisia tabaci en Costa Rica y Florida. Agronomía Mesoamericana 29:585-595

Hernández-Espinal L. A., I. Enríquez-Verdugo, C. M. Melgoza-Villagómez, J. E. Retes-Manjarrez, S. Velarde-Félix, P. J. Linares-Flores y J. A. Garzón-Tiznado (2018) Análisis filogenético y distribución de begomovirus en el cultivo del chile (Capsicum annuum I.) en Sinaloa, México. Revista Fitotecnia Mexicana 41:149-157.

Horas V. R., P. E. Degrande, C. E. Carducci and M. G. Fernandes (2018) Antibiosis and antixenosis resistance to oviposition by Bemisia tabaci (Gennadius) B biotype (Hemiptera: Aleyrodidae) in soybean genotypes. Arquivos do Instituto Biológico 85:e0982017, https://doi.org/10.1590/1808-1657000982017

Hossain M. A., M. D. Shah, C. Gnanaraj and M. Iqbal (2011) In vitro total phenolics, flavonoids contents and antioxidant activity of essential oil, various organic extracts from the leaves of tropical medicinal plant Tetrastigma from Sabah. Asian Pacific Journal of Tropical Medicine 4:717721, https://doi.org/10.1016/S1995-7645(11)60180-6

Jeevanandham N., M. Marimuthu, S. Natesan, K. Gandhi and S. Appachi (2018) Plant resistance in chillies Capsicum spp against whitefly, Bemisia tabaci under field and greenhouse condition. Journal of Entomology and Zoology Studies 6:1904-1914

Latournerie-Moreno L., A. Ic-Caamal, E. Ruiz-Sánchez, H. BallinaGómez, I. Islas-Flores, W. Chan-Cupul and D. González-Mendoza (2015) Survival of Bemisia tabaci and activity of plant defense-related enzymes in genotypes of Capsicum annuum L. Chilean Journal of Agricultural Research 75: 71-77, https://doi.org/10.4067/S0718-58392015000100010

Leckie B. M., D. A. D'Ambrosio, T. M. Chappell, R. Halitschke, D. M. De Jong, A. Kessler, G. G. Kennedy and M. A. Mutschler (2016) Differential and synergistic functionality of acylsugars in suppressing oviposition by insect herbivores. PLOS ONE 11:e0153345, https://doi.org/10.1371/journal.pone.0153345

Lowman M. D. and J. D. Box (1983) Variation in leaf toughness and phenolic content among five species of Australian rain forest trees. Australian Journal of Ecology 8:17-25, https://doi.org/10.1111/j.1442-9993.1983.tb01515.x

Matos C. H. C., A. Pallini, C. M. F. Pinto, M. Venzon, D. D. M. Rezende e R. C. P. De Freitas (2011) Caracterização morfológica e classificação da superfície foliar de pimentas quanto à presença de tricomas e domácias. Horticultura Brasileira 29:181-186, https://doi.org/10.1590/S0102-05362011000200008

McCreight J. D., W. M. Wintermantel and E. T. Natwick (2017) Host plant resistance in melon to sweetpotato whitefly in California and Arizona. Acta Horticulturae 1151:237-244 https://doi.org/10.17660/ActaHortic.2017.1151.37

Mwila N., S. Rubaihayo, S. Kyamanywa, T. L. Odong, E. Nuwamanya, M. Mwala, S. Agbahoungba and A. Badji (2017) Biochemical factors associated with cassava resistance to whitefly infestation. African Crop Science Journal 25:365-385, https://doi.org/10.4314/acsj.v25i3.9

Ohmart C. P., J. R. Thomas and L. G. Stewart (1987) Nitrogen, leaf toughness and the population dynamics of Paropsis atomaria Olivier (Coleoptera: Chrysomelidae)-a hypothesis. Australian Journal of Entomology 26:203-207, https://doi.org/10.1111/j.1440-6055.1987.tb00286.x

Oriani M. A. G., J. D. Vendramim and C. J. Vasconcelos (2011) Biology of Bemisia tabaci (Genn.) B biotype (Hemiptera, Aleyrodidae) on tomato genotypes. Scientia Agricola 68:37-41, https://doi. org/10.1590/S0103-90162011000100006

Padhi G. K., L. Maity, A. Chattopadhyay and A. Samanta (2017) Population dynamics of whitefly (Bemisia tabaci Genn.) in chilli and screening of genotypes against chilli leaf curl virus. Journal of Entomology and Zoology Studies 5:104-107.

Polston J. E., P. De Barro and L. M. Boykin (2014) Transmission specificities of plant viruses with the newly identified species of the Bemisia tabaci species complex. Pest Management Science 70:15471552, https://doi.org/10.1002/ps.3738

Rakha M., P. Hanson and S. Ramasamy (2017) Identification of resistance to Bemisia tabaci Genn. in closely related wild relatives of cultivated tomato based on trichome type analysis and choice and no-choice assays. Genetic Resources and Crop Evolution 64:247-260, https://doi.org/10.1007/s10722-015-0347-y

Rodríquez-López M. J., E. Garzo, J. P. Bonani, A. Fereres, R. Fernández-Muñoz and E. Moriones (2011) Whitefly resistance traits derived from the wild tomato Solanum pimpinellifolium affect the preference and feeding behavior of Bemisia tabaci and reduce the spread of Tomato yellow leaf curl virus. Phytopathology 101:11911201, https://doi.org/10.1094/PHYTO-01-11-0028

Scott A. J. and M. Knott (1974) A cluster analysis method for grouping means in the analysis of variance. Biometrics 30:507-512 https://doi.org/10.2307/2529204

Smeda J. R., A. L. Schilmiller, R. L. Last and M. A. Mutschler (2016) Introgression of acylsugar chemistry QTL modifies the composition and structure of acylsugars produced by highaccumulating tomato lines. Molecular Breeding 36:160, https://doi.org/10.1007/s11032-016-0584-6

War A. R., M. G. Paulraj, T. Ahmad, A. A. Buhroo, B. Hussain, S. Ignacimuthu and H. C. Sharma (2012) Mechanisms of plant defense against insect herbivores. Plant Signaling and Behavior 7:1306-1320 https://doi.org/10.4161/psb.21663

Westbrook J. W., K. Kitajima, J. G. Burleigh, W. J. Kress, D. L. Erickson and S. J. Wright (2011) What makes a leaf tough? Patterns of correlated evolution between leaf toughness traits and demographic rates among 197 shade-tolerant woody species in a neotropical forest. The American Naturalist 177:800-811, https://doi.org/10.1086/659963 
